Acta Orientalia Academiae Scientiarum Hung. Volume 54 (2-3), 319-338 (2001)

\title{
WAS THERE GEOGRAPHICAL SCIENCE IN SASANIAN IRAN?*
}

\author{
DAN SHAPIRA** \\ (Tel-Aviv)
}

\begin{abstract}
The study examines the extant Sasanian material relating to geographical knowledge, trying to answer the question whether Iranians of the Late Sasanian period possessed the notion of "geographical science" comparable to that of their Byzantine neighbours or their Islamic heirs. Geographical traditions found in several texts, both in Avestan and Pahlavi, are studied and compared, in order to reach the conclusions, whether the actual geographical knowledge was systematised. It appears that there was much diversity in geographical views in various periods of Sasanian history; the views on geography were generally geopolitically motivated; there was a gap between the learned traditions and real geographical knowledge; Sasanian geographical attitudes were characterised by Iranocentrism and little interest in real geography; Sasanian Iranians did not develop a geographical science, and much of what we are left with is rather geographical mythology.
\end{abstract}

Key words: Sasanian geography; Bundahišn; Vendidād; Ayādgāerr-ī Jāmāspīg; administrative division; Iran and China; Iran and Turks; Iran and India.

Much work has been done in the fields of the historical ${ }^{1}$ and mythical ${ }^{2}$ geography of Ancient and Sasanian Iran, but the purpose of this paper is to deal with the question whether Iranians of the Late Sasanian period had what we could designate as "geographical science," i.e., how did they perceive their own country and the world surrounding it? Sasanian Iranians naturally knew a great deal about their own country and the lands outside Iran. ${ }^{3}$ The question I want to examine is whether this actual knowledge was systematised and seen as worthy of study, as was the case in the Greek-speaking world, or, later, in the Islamic world. ${ }^{4}$

* This study is based on the paper read at the $4^{\mathrm{e}}$ Conférence européenne d'études iraniennes, September 2000, Paris.

* Dr. Dan Shapira, Department of History and Philosophy, and Center for Education, Open University of Israel, Klausner St. 16, Ramat-Aviv, Tel-Aviv, P.O. 39328, Israel, (home) HaMetsadim 103b, Ma'aleh-Adummim, Israel. Tel: (office) 972-2-5883972; (home) 972-2-5357197; 972-25357215; mobile: [972-]51-623059, e-mail: dshapira@h2.hum.huji.ac.il

${ }_{1}^{1}$ See, e.g., Justi (1869); Tomaschek (1883); Geiger (1904); Gnoli (1980).

2 On the concept, cf., e.g., Corbin (1977).

${ }^{3}$ On such actual geographical knowledge, see Utas (1976); Cereti (1994).

${ }^{4}$ My own interest in Sasanian geography was motivated by two different reasons: firstly, by my research on the Arabic and Persian geographers who wrote on the Khazars and related topics, 
We will first turn to three versions of one geographical tradition found in the muchdiscussed first fragard of $\operatorname{Vendidad}^{5}[=\mathrm{Vd}]$, or Widēwdād, a late Avestan text; this tradition is preserved in the Avestan original and in two Pahlavi versions, namely in Pahlavi Vendidad [= PhlVd] and in Bundahišn $[=\mathrm{Bd}] 31 .^{6}$

The order of the lands listed in this Avestan text, with their Pahlavi equivalents as listed in the Pahlavi Zand of Vd, is as follows:

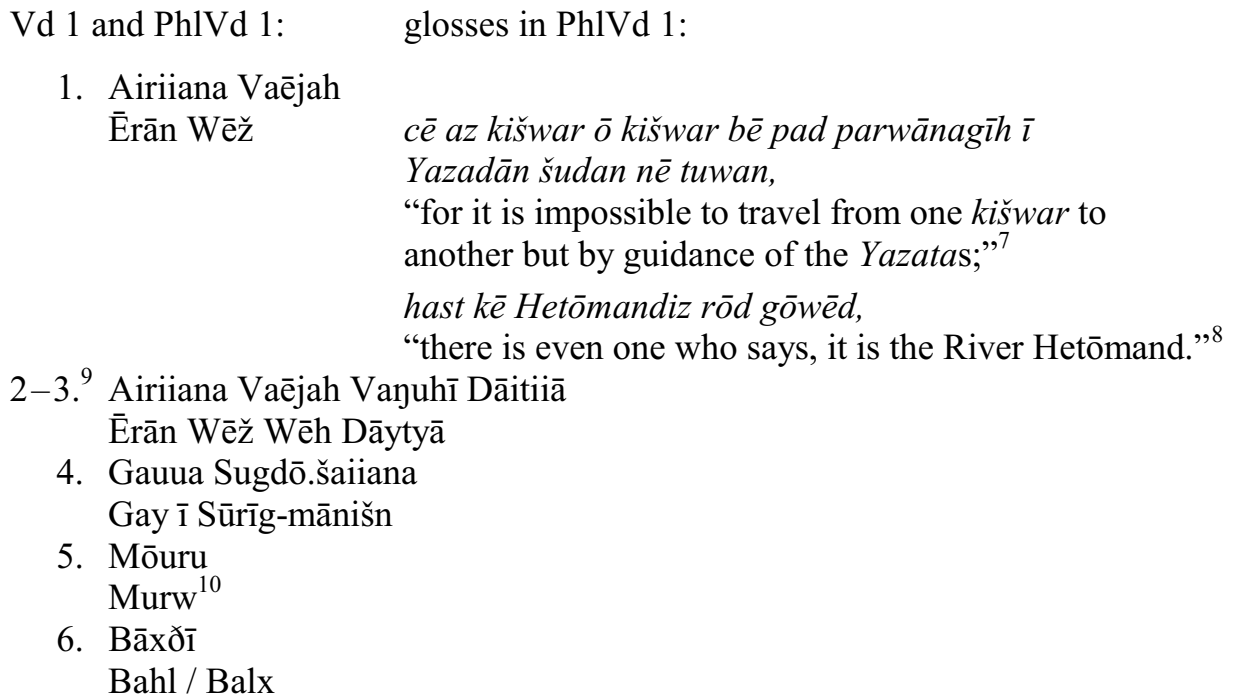

1. Airiiana Vaējah Ėān Wēž

cē az kišwar ō kišwar bē pad parwānagīh $\bar{l}$

Yazadān šudan nē tuwan,

"for it is impossible to travel from one kišwar to another but by guidance of the Yazatas;",

hast kē Hetōmandiz rōd gōwēd,

2-3. ${ }^{9}$ Airiiana Vaējah Vayuhī Dāitiiā

"there is even one who says, it is the River Hetōmand." 8 Ērān Wēž Wēh Dāytyā

4. Gauua Sugdō.šaiiana Gay 1 Sūrīg-mānišn

5. Mōuru

Murw $^{10}$

6. Вāxð̄̄

Bahl / Balx

cf. Shapira (forthcoming/1), and secondly, by my work on Bundahišn, the Middle Persian compendium of traditional lore.

${ }^{5}$ See Christensen (1943); Molé (1951); Humbach (1960); Gnoli (1980, passim). See now Cantera Glera (1998).

${ }^{6}$ It is evident that Chapter 31 of the Iranian Bundahišn has the first fragard of the Pahlavi Vendidad as its source, cf. Christensen (1943, passim); Boyce (1968, p. 19); MacKenzie (1989a, p. 548).

${ }^{7}$ There is a practically identical text in Bd 8(11).4: az kišwar ō [kišwar] jud pad parwānagīh $\bar{\imath}$ Yazadān warzāwandīh tā šudan nē šâyed, "it is impossible to travel from one kišwar to another except by the guidance and miraculous power of the Yazatas," and from the context there we can identify Ërān Wēž, "the Iranian Homeland" in our passage in PhlVd 1.1 with X anīrah, the central inhabited continent of the Ancient Iranian worldview.

${ }^{8}$ The River Hêtōmand (Hilmend) is said to be in Sagestān. It was connected with the deeds of Frāsyāb (Bd 11.12, 32). p. $23 \mathrm{ff}$.)

9 This and the next passages belong to the "second redaction", cf. Christensen (1943,

${ }^{10} \mathrm{Cf}$. the remarks of Christensen (1943, p. 15); cf. also Shapira (1998, Vol. I, Introduction, p. xlvii, and note 195). It should be noted, however, that the Zandist was transcribing the Avestan form, ignoring the existing Middle Persian one. This was how the mistakes arose, necessitating the glossing work of later copyists who had no Avestan original before them. 
7. Nisāiia

Nisāy

8. Harōiva

Harēw

9. Vaēkərəta

Wēgard

Kābul

10. Uruuā

Mēšān

11. Xnənta yim vəhrkānō.šaiiana

$X n a n^{11} \overline{1}$ Gurgān mānišn

12. $\operatorname{Harax}^{\mathrm{v}}$ aitī

Harahmand $^{12}$

13. Haētumant

Hētōmand

Sīst [*ān?]

15. Raga

Rag

$\bar{A} d u r b \bar{a} d a g \bar{a} n$, hast kē Ray gōwēd, “A., some say: R."

16. Čaxra

Čaxr

$* \operatorname{Maz} \bar{u} n^{13}$

17. Varəna yim ča $\theta$ ru.gaoša Warn 1̄ čahār-gōš Padišxwārgar; Daylam / Gēl; ${ }^{14}$ Kirmān

18. Hapta Həndu Haft-Hindūgān

19. Upa aōdaēšu rayhaiiā $[\ldots]$ taožiiāča abar pad Ōdāg $\overline{1}$ Arwestān ${ }^{15} \overline{1}$ Hrōm

20. Pārs.

As has been observed, the order of enumeration of the lands in this Avestan source is as follows: $\mathrm{NE}>\mathrm{S}>\mathrm{W}>\mathrm{N} .^{16}$ The work of the Zandist made the order of the list chaotic, due to his identifications of some of the Avestan lands with more fa-

${ }^{11}$ Written in Avestan characters.

${ }^{12}$ The form is corrupt, cf. Christensen (1943, p. 37).

${ }^{13}$ Which is Oman, see Marquart (1901, p. 43 and note 4); cf. now Cantera Glera (1998, Vol. II, p. 35). On the form Mazūn, cf. de Blois (1989).

${ }_{15}$ See Cantera Glera (1998, Vol. II, p. 38 note 3).

${ }^{15}$ Avestan: "at the source of the Ranha River;" cf. also Yt 12.18, for which no Pahlavi version exists; most scholars read in PhlVd 1.19 Arangistān ( $\overline{\partial \bar{a} Y} Y^{\prime}$ 'ngysty'n $Y$ hlwm), where I read (after Marquart (1901, p. 165) and Christensen (1943, p. 58) Arwestān (the $w$ is from Ara-

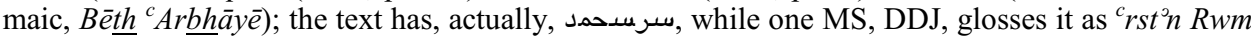
(عرستات روم), sic!), cf. Dastoor Hoshang Jamasp (1907, pp. 18-20, note 2). MacKenzie (1989a, pp. 548b-549a) noted that Avestan Rayha / Pahlavi Arang was identified with Pahlavi Arwand, properly Orontes, but confused with the Tigris. Cf. Shapira (1998, Vol. I, Chapter 2, pp. 66ff.).

${ }^{16}$ Cf. Christensen (1943, p. 53); compare now Gnoli (1989, pp. 45b-46a): if one would map the localities according to Gnoli's identifications, the result will be basically the same. The theory that Vd I conserves the names of some Western lands in boustraphedonic order [cf. Nyberg (1938, pp. 324ff.)] has no foundation, see Gnoli (1980, pp. 59ff.), and Gnoli (1989, p. 44a). 
miliar - and important - Western lands, such as Syria (instead of Sogdiana ${ }^{17}$ ), Mēšān (instead of Uruuā), Ādurbādagān and Ray (instead of Ragậ), Padišxwārgar, Daylam / Gēl[ān], Kirmān (instead of Varəna yim ča $\operatorname{ru}$ ru.gaoša), and Bēth- ${ }^{\mathrm{c}}$ Arbhayye ${ }^{18}$ on the Byzantine frontier (instead of Upa aōdaēšu rạhaiiā); in addition, two localities seem to be identified with their namesakes in the Iranian West (Nisā and Raya). However, the tendency to draw a concentric ring was preserved: it is worth noting that the Zandist began from the mythical Iranian homeland and finished in Pārs, the heartland of the Sasanian Empire (thus providing us with the clue enabling to date the Zand).

This tendency to draw a concentric ring is even more clear in the second list which represents the order of the lands according to $\mathrm{Bd} 31$ (this list is based on PhlVd, not on the Avestan Vd):

1. Ērān-Wēž

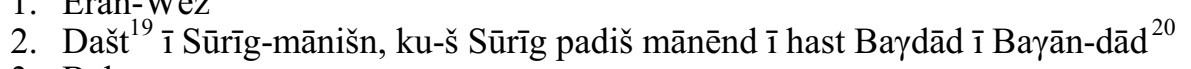

3. Balx

4. Marw

5. Nisāy $\overline{1}$ andarag Marw ud Balx

6. Harēw

7. Kābul $[\ldots]^{1} \mathbf{1}$ hast Kābulestān

8. Mēšān

9. Xnạn $\overline{1}$ Gurgānīg-mānišn

10. *Armān ${ }^{21}$

10. Hēdōmand [...] Sagīstān

11. Rāg $[\ldots] \overline{1}$ hast Ādurbādagān

12. Wahār ${ }^{22}[\ldots]$ kē hast $\overline{1}$ Mazūn ${ }^{23}$

${ }^{17} \check{S} a h r \bar{E} r \bar{a} n 5$ (cf. note 27 below) seems to identify Sogd with Samarqand, see Markwart Messina (1931, p. 9).

${ }^{18}$ Arbayestān between Bezabhde and Nineveh, Nisibis and Pērōz-Šāpūr, cf. note 15 above. MacKenzie (1989a, pp. 548-549): Orontes/Tigris.

${ }^{19}$ Why Gay of the version of PhlVd became changed to dašt? It may be a scribal error, as in the Pahlavi writing both words have some similarity; it may be translation, as Gava in Avestan means Gau or plain (cf. AiW 509a); the possibility that dašt is the huzwārišn of an (unattested) Aramæogram, *G[A]Y[TA], compare Hebrew $g^{2} y$, "valley", is purely speculative.

${ }^{20}$ This is the "a right" etymology, on the popular level. Cf. Shaked (1985).

${ }^{21}$ Cf. MacKenzie (1989a, p. 548b), cf. Christensen (1943, p. 37). Armenia in the list of Bundahišn was inserted instead of Harax ${ }^{\mathrm{v}}$ aitī, Arachosia [in Pahlavi: Harahmand; the form is corrupt, cf. Christensen (1943)]. Such substitution of Armenia instead of an ancient Eastern-Iranian country implies that in, at least, one Iranian tradition Armenia was seen as part and parcel of Iran, see Shapira (1999-2000, p. 144 and note 14). Cantera Glera (1998, Vol. II, p. 25), read harmun.

${ }_{22} \mathrm{Cf}$. Zand $\overline{1}$ Wahman Yasn 7.7, where the reading is, however, highly uncertain: awē Kay ka sīh sālāg bawēd [hād būd kē āwām guft] pad amar draf̌s spāh, spāh ì Hindūg ud Čènīg ul grift

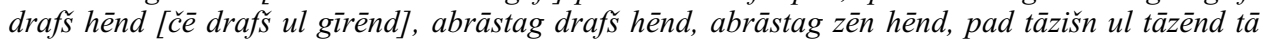
Wehrōd [hād būd kē Bumē deh guft] tā andarag bār ì bahr ì bahrān, Spitāmān Zardu[x] št!', "When the Kay will be thirty years of age [there was someone who mentioned the time], the armies with innumerable banners, the Indian and the Chinese armies having up-raised banners [for they will raise the banners aloft], having erect banners, having erect weapons, they will make razziahs upto Wehrōd [there was someone who said it was the Bumē village] upto the interior of the shore of the sea of *Bahrain (?), O Spitāmān Zoroaster!” Cereti (1995) read here Balx (*Balx ì bümīg?).

${ }^{23}$ See note 13 above. 
13. War $\overline{1}$ cahār-gōš $[\ldots]$ hast $\overline{1}$ Dumbāwand

14. Haft Hindūgān

15. *Ōdag Arand [...] hunušak $\overline{1}$ Tāzīgān Ōdag [...] Tāzīg abar mānēnd ${ }^{24}$

16. Pārs

This is basically the same list, but disconnected from its Avestan original - or from its learned Pahlavi rendering, which abounds with glosses - it has become an independent document. First of all, the order: instead of the concentric movement of the Avestan list (though with some deviations in the Pahlavi version), which began from NE ( $\bar{E} r \bar{a} n W \bar{e} z \bar{z})$ and ended in N, we have here the movement inside Ėrān Wēž, which is thus identified with the Iranian Empire, and in a broader sense, with the $\mathrm{X}^{\mathrm{V}}$ anirah clime, or continent, at whose centre, ${ }^{25}$ in Pārs, the list is coming to its end. This was achieved by converting an out-of-hand gloss (Pārs) of PhlVd into an integral part of the new text and by omitting any connection of Ērān Wēž with the Däitiiā River. Ironically, the pure land of the pre-Avestan Iranians, $S u \gamma \delta a$, became Sasanian Mesopotamia and Djazīra, Dašt i Sūrīg Mānišn, which was, together with Mēšān (also mentioned in the text), the "non-Iran" for the Kings of Ērān and nonËrān. ${ }^{26}$ Moreover, instead of the old Iranian Čaxra, Oman (Mazūn) appeared in the list, and finally, the Arabs were introduced, having been begotten by a combination of an untranslated Avestan word (taožiiāča), similar in sound to the Pahlavi for "Arabs", and Arwestān ì Hrōm ("Roman Arabia"), which is Bēth- ${ }^{\mathrm{c}}$ Arbhayyē in Northern Mesopotamia. What we have in this list is actually a list of provinces of the Late Sasanian Empire, not geography. This list appears to be close in character to that found in the composition of a post-Sasanian date known, in the extant recension, as Šahrestānīhā $\bar{\imath}$ Érānšahr [ŠahrĒrān]. ${ }^{27}$ Before we turn to the list of ŠahrĒ rān, I would note that the compiler of the $\mathrm{Bd}$ list was tied to identifications of places found in his source, without a possibility to add entirely new items for which his Zand had no authority; ${ }^{28}$ the situation of $\breve{S} a h r \bar{E} r \bar{a} n$ is different - there the author was interested in founding-legends connected with particular towns and localities.

\section{II}

The order of the enumeration of the four great vice-royalties in $\breve{S} a h r \bar{E} r \bar{a} n$ is said to be crisscrossed, East $>$ West $>$ South $>$ Ādurbādagān $(N W):{ }^{29}$

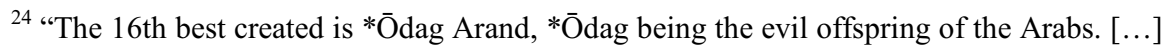
The Arabs live there," see Shapira (1998, Vol. I, Chapter 2, pp. 66ff.).

${ }^{25}$ Cf. note 7 above. Cf. Gnoli (1989, p. 47).

${ }^{26}$ On this term, cf. Gignoux (1987, pp. 30-31); Gnoli (1985); Gnoli (1986), and the bibliography given there. mova (1994).

Editions and translations: Markwart - Messina (1931); Markwart (1938, passim); Kasu-

${ }^{28}$ The only exception being the reference to Armenia, which could have been caused by a scribal confusion.

${ }^{29}$ I give here a partial list. 
$\mathrm{X}^{\mathrm{v}}$ arāsān (Samarkand, *Sugd, ${ }^{30}$ Baxl, $\mathrm{X}^{\mathrm{v}}$ ārazm, ${ }^{31}$ Marw, Harāt, Tōs, NēwŠāhpuhr, Kāyēn, Gurgān [Šahrestān 1 Dahestān], Kōmis, Čōl ${ }^{32}$ );

X arbarān (cities built by Husraw I and II, Tēsîfōn, Neșībīn, Urhā, ${ }^{33}$ Bābhīl, Hīrat, ${ }^{34}$ Hamadān, Māy, Padišxwārgar, Dumbāwand, Nihāwand, Wēsutūn, Dēnabarān, Musarakān, Balōčān, Marinjān, Mauṣil, Jazīra, Šām, Yaman, [*A]Frīkā, Kūfāh, Makkā, Madīna $\left.{ }^{35}\right)$;

Nēmrōz (Kābul, Raxwat, ${ }^{36}$ Bust, Farāh, Zawulestān, Zrang, Kirmān, Weh-Ardašēr, Staxr, Weh-Šāpūr, Dārābgird, Tōbag, Šūš ud Sūstar, Wand<iy>ōg-Šāhpuhr, Nahr Tīrag, Ērān-X arrah-Kard-Šāhpuhr = Bēlabat, Samrān, ${ }^{37}$ Āsūr 1 šahrestān 1 Weh-Ardašēr, Hagar, Gay = Isfāhān, Ērān-Āsān-Kard-Kawād);

Ādurbādagān (Ganzag, Wan, Amūi, Rāy, Baydād ${ }^{38}$ ).

First, one notes that the region of Nēmrōz, designated by the word for "South,"39 comprised, in fact, much of Iran, from Madā'in / Mahōzē (Ctesiphon), ${ }^{40}$ via Iṣfāhān, Farāh, up to Kābul, down to the Indian Ocean, and then to the Sasanian possessions in Arabia and Yaman. As we can see, this list is arranged on the basis of the quadripartite division of the Iranian Empire, which was made under Husraw I (531-579), but with many post-Sasanian additions and, perhaps, with some errors in the lists of the towns located in the four great vice-royalties. ${ }^{41}$ According to Arabic

${ }^{30}$ See Kiā (1958); Kiā (1975); Utas (1976, p. 116); Tafazzoli (1990, pp. 47-48).

${ }^{31} \breve{S} a h r \bar{E} r \bar{a} n 10 \& 47$ are aetiological legends on the density of the Jewish population in $\mathrm{X}^{\mathrm{v}}$ ārazm (Kat) and Susa, cf. Zand (1988, pp. 8-9) [Hebrew].

${ }^{32}$ This place was said to be located on the SE side of the Caspian, cf. Marquart (1903, p. 489). However, the locality with the same name is well known on the Western side of the Caspian, near Darband, and it is plausible to suggest that on our list it was displaced.

${ }^{33}$ The list of $\breve{S} a h r \bar{E} r \bar{a} n$ in the West (Urhā- = Edessa, Syria, Yaman, Africa) probably reflects conditions of the early 7 th century, cf. Morony (1982, p. 6).

${ }^{34}$ Which is al-Hīira on the War i Tāzīgān (the Persian Gulf, cf. Markwart - Messina (1931, p. 67).

${ }^{35}$ On the last names, among them Africa, cf. Markwart - Messina (1931, pp. 82-83). As to Yaman, Kūfāh, Madīna (and, most probably, Makkā), it seems to be a post-Islamic gloss, cf. Samrān below. Compare note 33 above.

${ }^{36}$ Harax $a i t \overline{1}$, cf. Markwart - Messina (1931, p. 84). Note that here it was not identified with Armenia.

${ }^{37}$ = Himyar, compare Yaman above; see Shapira (forthcoming/2), "Between Himyar and Māzandarān: Pahlavi traditions of Husraw Anōšurwān's Wars". Markwart - Messina (1931, pp. 101-102) explained the name of the Himyarite king appearing in the text under consideration and written Masūr as Mansūr; I would guess this could be a corrupt form of *Masrūq.

${ }^{38}$ Bagdād, already mentioned in this Western section as Ctesiphon, is out of place in the Northern section; it seems that Baydād, as the capital, finishes the list, similarly to the position of Pārs in earlier Sasanian lists.

${ }^{39}$ This administrative meaning of the word should be kept in mind while dealing with some apocalyptical passages, in which the redeemer is said to come from "Nēmrōz". This vague term can mean "from Pārs", or "from Kābulestān", or even "from Arabia". Mahōzē

${ }^{40}$ The region of the "West" had a common border with the Nēmrōz-unit in Madā̄in /

${ }^{41}$ Cf. Gignoux (1984); Gignoux (1992); Gyselen (1989). 
authors, Husraw I Anōšurwān (531-578) divided Iran into four big units, not of the same size: ${ }^{42}$ East, North, South, West. Al-Yaqūbi ${ }^{-43}$ and al-Tha ${ }^{\mathrm{c}} \overline{\mathrm{a}}$ lib ${ }^{-44}$ listed them as follows: Xurāsān; Kuwar al-Jabal (Media, etc., including Isfāhān); Fārs with Kirmān and Ahwāz; al- ${ }^{\mathrm{c} I r a ̄ q ~ u p ~ t o ~ a l-Y a m a n ~ a n d ~ t h e ~ S y r i a n ~ b o r d e r ~}{ }^{45}$ (or Xurāsān; Xurbārān / Maghrib; Nīmrūz / Fārs; Āðarbajān / Kuwar al-Jibāl).

This order reflects the importance given to the Eastern and Northern borders in the time of Husraw I. No connection to the learned traditions of the Zandists could be seen here. Another list, dating from the first third of the 7 th century, ${ }^{46}$ is found in the so-called "Armenian Geography", or Ašxarhac ${ }^{c}$ oyc ${ }^{c}, 47$ by Anania of Šrak, which is the most comprehensive description of the Late Sasanian Empire. The actual description of Iran divided into four appears only in the Long Version (29). ${ }^{48}$ There the order is against the clock: West, South, East, North $\left(k^{c} u s t i{ }^{*}\right.$ Xorbaran, ${ }^{49} k^{c} u s t i$ Nmroj, ${ }^{50} k^{c}$ usti Xorasan, $k^{c} u s t i$ Kapkoh $^{51}$ ), and again, this order seems to be based mostly on the political, and not on the geographical considerations.

${ }^{42}$ In this respect, a note should be made in passing: in Mazdak's theology, a description of which survives in Šahrastān̄’s Arabic, the word xusraw appears, with the meaning of "king", see Shaki (1985, pp. 532-533). This usage looks strange, as Husraw I Anōšurwān was the king who executed Mazdak soon after he rose to power, and one would speculate that this word was perhaps provoked by the phonetically similar word kursī appearing in the same sentence. However, the same description of Mazdak's theology has only one spähbed instead of the four in the Husraw's times. Should we combine these facts and guess that this piece of Mazdak's theology was written after Husraw ascended to the throne, but before his break with Mazdak and the establishment of the four spāhbed-ships?

${ }^{43}$ Kolesnikov (1970, pp. 95ff.); cf. also Kolesnikov (1981) [on marzbān, cf. also Gignoux (1985)]; Kolesnikov (1982).

${ }_{44}$ Zotenberg (1900, p. 609); cf. Brunner (1983, pp. 748ff.).

${ }^{45} \mathrm{al}^{-T h}{ }^{c} \mathrm{a}$ alibì called the four units $r u b^{c}$; the Pahlavi term was kustag or pādgost. The Middle Persian $\bar{p} \bar{a} d g o s t$, "one of the four parts of Ërānšahr after Anōšurwān", was happily translated as

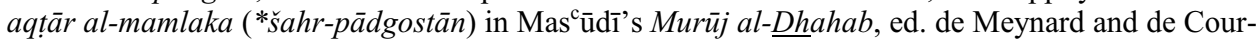
teille (1914, Vol. II, p. 152); the Arabic aqtār, Plural of quțr, "region, zone, quarter" [see Wehr (1976, p. 774)] seems to be borrowed from the Latin (via Greek and Syriac) for "quarter"; this Arabic word has no Semitic etymology (the Hebrew qóter, "diameter", is a medieval borrowing from Arabic). The Arabic of the (spurious) throne speech of Ardashir has [...] iqāmat al- ${ }^{c}$ adl wa-

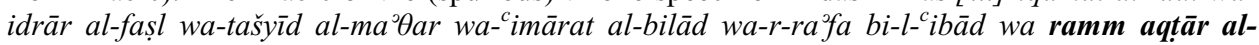
mamlaka, which may be tentatively reconstructed in Pahlavi as follows: *paymān-āxistan ud dādradēnīdan (rāwēnīdan/rawāgēnīdan?) ud kirbag-pāādyāwastan ud šahr-ābādīh ud mardomxurramīh ud ab̄̄z wirāstan ì šahr-pādgostān.

${ }^{46}$ Compiled prior to 636, cf. Hewsen (1992, pp. 13-15).

${ }^{47}$ Marquart (1901); Hewsen (1992).

${ }^{48}$ Cf. Hewsen (1992, pp. 72-75).

${ }^{49}$ Including Adiabene, cf. Hewsen (1992, pp. 229-230).

${ }^{50}$ Including two islands, Ger and Mēšmanxik, in the Persian Gulf, Xužihrestān, and Spahl and Debuhēl, taken from the Indians. It should be noted that Yaman is absent from this list. In the period when the text was composed, Yaman was not under Sasanian rule.

${ }^{51}$ I.e., the Mountain of Kāf, Caucasus; it included, i.a., Armn, Varjan, Ran, Balasakan, *Sisakan [Siwnik ${ }^{\mathrm{c}}$, cf. Hewsen (1992, p. 234)]. 
A much earlier list, from the third century, is found in the description of the Sasanian

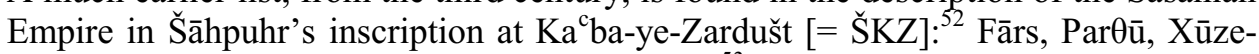
stān, Mēšān, Asūrestān, *Nōrširakān = Adiabene, ${ }^{53}$ Arabestān = Bēth ${ }^{\circ}$ Arbhāyēē, Ādurbadigān, Armēn, Wručan / Wirušān = Iberia, Sēkān, ${ }^{54}$ Alwān/Arrān = Albania, ${ }^{55}$ Bālasagān, up to in front of (or facing) the Caucasus and the Alanian Gate (tā frāz ō Kāfkōh

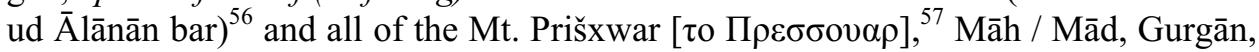
Marw, Harēw, *Parthian ( $\left.{ }^{2} p r h s ̌ t r, ~ * A b a r s ̌ a h r\right)$ provinces: Kirmān, Sagestān, Tūrān, Makurān, Pārtān, Hindūstān, Kušānšahr up to in front of (or facing) ( $t \bar{a}$ frăz ō) Paškubar

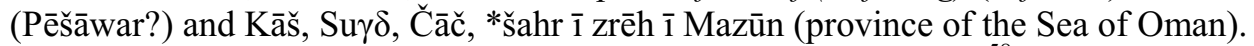

In the inscription[s] of the Zoroastrian "Pope" Kirderr $(\S 14)^{58}$ belonging to the same period, the list of the lands of "Iran", as opposed to "non-Iran", is basically the same, with slight variations in the order: Fārs, Pahlaw̄, Xūzestān, Asūrestān, Mēšān, ${ }^{59}$ *Nōdširakānř, Ādurbadigān, Spāhān, Ray, Kirmān, Sagestān, Gurgān, Marw, Harēw, Abaršahr, Tūrestān, Makurān, Kušānšahr up to ( $t \bar{a}$ frāa $z$ o) Paškabūr (Pēšāwar?).

One can see that in these two lists the order is West, North-East, East, South, beginning from Pārs and finishing on the opposite shore of the Persian Gulf; again, the order reflects, in my opinion, the geopolitical conditions of the age; this is at odds with Narsēh's inscription at Paikuli (§ 92-93), ${ }^{60}$ which belongs to a slightly later date, and in which the two lists of kings and greater rulers and of lords and lesser rulers begin in the East and go westwards. ${ }^{61}$

So, we have seen that the Sasanian lists of localities did not represent a uniform tradition and there is nothing that could qualify them as "geography".

\section{IV}

It should be added that there was another geographical tradition current in Sasanian Iran: according to Kramers, ${ }^{62}$ Yāqūt tells that Ardašīr I drew a map of the world, and

${ }^{52}$ Cf. Henning (1939); Henning (1954); Honigmann and Maricq (1953); Maricq (1958, pp. 306-307, 336-337); Back (1978, pp. 286-287). More bibliography in Cereti (1995-1997, pp. 19ff.).

${ }^{53}$ Cf. Hewsen (1992, pp. 229ff.). Mingrelia.

${ }^{54}$ Mingrelia or Siunik ${ }^{\mathfrak{c}}$ ?; according to Skjærvø (1983, P. 3.2, p. 126, with bibliography), not

${ }^{55}$ See Gnoli (1998, p. 164).

${ }^{56}$ See Gnoli (1998, pp. 164-165).

${ }^{57}$ Back (1978, p. 287): “die ganze Elburzkette (= Tabārestān und Gēlān)."

${ }^{58}$ See Back (1978, pp. 420-422); for the texts, see now MacKenzie (1989b, pp. 43, 55, tr. on p. 58), and Gignoux (1991, p. 50, tr. on p. 71). On the list(s), compare Gignoux (1971).

${ }_{59}$ Note that the order is different than that of the ŠKZ. Note also that Xūzestān, Asūrestān and Mēšān appear on the list of "Iran”, cf. Gignoux (1971, pp. 89-90).

${ }^{60}$ See Skjærvø (1983, P. 3.1, pp. 70-73).

${ }^{61}$ Skjærvø (1983, P. 3.2, pp. 121-122.

${ }^{62}$ Kramers (1938, p. 64a). 
a similar tradition was told by [Pseudo-]Ṭūsī ${ }^{63}$ in ${ }^{c} A j \bar{a}{ }^{\top} i b$ al-Makhlū $q \bar{a} t$ about Kubād. In fact, Yāqūt's text says: "it was told of Ardašīr that he said that the Earth is divided into four parts: ${ }^{64}$ one part is the land of the Turks, and it is located between the West of India up to the East of Byzantium; one part is the West, namely what is between the West of Byzantium up to Egypt [al-Qibt] and Barbary (Somali); one part is the land of the Blacks [al-Sūdān], and it is located between Barbary (Somali) up to India; one part is the land which belongs to Persia $[a l-F a \bar{r} s]$ : what is between the River of Balkh up to the outskirts of Ādharbaydjān and Persarmenia [al-Armaniyya al-Fārisiyya], then up to the Euphrates, the Arab Desert up to Oman and Mukrān, then up to Kābul and Ṭakharestān [...]."

Here we have a fourfold division of most of the inhabitated world (except China and India), with Iran at the centre, which is described in the following order: $\mathrm{NE}>\mathrm{NW}>\mathrm{SW}>\mathrm{SE}$.

\section{V}

Now, if we turn to the great Pahlavi compendia of the traditional Zoroastrian lore, namely, the Dēnkard [= Dk] and Bd (Bundahišn), we find out that though much foreign wisdom was translated into Pahlavi and incorporated in the Late Sasanian Avesta (including material on philosophy, astronomy and astrology), nevertheless, geography, Greek or Indian, attracted apparently no attention. There is no Avestan Nask summarised in the Dk, about which we could say that it used to contain any geographical knowledge. There are here and there geographical allusions scattered in the Dk, but they are of no value for our subject or reflect the impact of Muslim geography. ${ }^{66}$

The Bd, a large Pahlavi work based mostly on the Pahlavi versions of Yašts, contains numerous geographical chapters, ${ }^{67}$ one of them being the already discussed

${ }^{63}$ Gharāì al-Mawjūiāt $w a^{c} A j \bar{a}{ }^{\curvearrowright} i b$ al-Makhlūquat (ed. Sutūde, 1345/1966), said to have been penned by Aḥmad Ṭūsī, should be attributed correctly to Najīb Hamadān̄i, see Smirnova (1993, p. 27ff.). of Tansar."

${ }^{64}$ Many res gesta of Anōšurwān were ascribed to Ardašīr, see, e.g., the case of "The Letter

${ }^{65}$ Mucjam al-Buldān, see von Wüstenfeld (1866, pp. 16-17); cf. also Dimašqī, ed. Mehren (1866, p. 18); Maqrīzī, Le Caire (1911, Vol. I, p. 33 [17]).

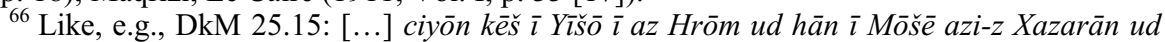

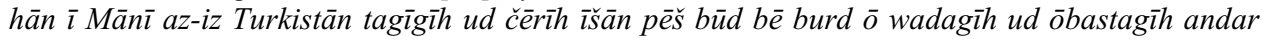
hamahlān abgand han $\bar{\imath}$ Mānì az Hrōm filsō [k]fäyīhiz anāft, "[...] like the faith of Jesus from Byzantium, and the faith of Moses from the Khazars, and the faith of Mani from the Uigurs took away the strength and the vigor they had previously possessed, threw them into vileness and decadence amongst their rivals, and the faith of Mani even frustrated the Byzantine philosophy," cf. de Menasce (1945, pp. 239-240); Molé (1967, p. 237). This passage was seen as reflecting the Uigur Manichæism, cf. de Menasce (1945, p. 240), and as one of the few non-Muslim sources to make note of Khazar Judaism, see Golden (1984, p. 140, note 38); cf. also Shapira (forthcoming/1).

${ }^{67} \mathrm{Bd} 8$ (11), "On the nature of the lands;" 9 (12), "On the nature of the mountains;" 10 (13), "On the nature of the seas;" 11 (20), "On the nature of the rivers;" $11 \mathrm{~A}(20)$, "On particular rivers;" 
$\mathrm{Bd}$ 31. Some geographical information is also found scattered elsewhere, e.g., in $\mathrm{Bd}$ 14 and 14B, "On the negroes", but it is outside of our inquiry here. ${ }^{68}$

Bd 8 (11), "On the nature of the lands," is the only chapter that provides a short exposition of the traditional Zoroastrian concept of seven kišwars, and is not merely a list of names. According to Kramers in his above mentioned classical article in the Encyclopaedia of Islam, the seven climes of the Muslim geography were perhaps influenced by Persian seven kišwars, with the map of al-Ma mūn divided into seven aqālim, six of which surrounding a seventh, the whole being surrounded by the encircling ocean. ${ }^{69}$ This is indeed the world-map described in Bd 8 (11).

Bd 9 (12), "On the nature of the mountains," also contains mythical information, ${ }^{70}$ with a few later additions, such as the mentions of Pārs (Bd 9.12, 24, 40), Sagestān (Bd 9.18), Hrōm = Byzantium (Bd 9.92), Kābul and China (Bd 9.3, 25, 39), Ādurbādagān (Bd 9.29), Turkestān and Spāhān and Kirmānšāhān (Bd 9.3, 43-44), and Mt. Baqąr (the Brazen City) and its stronghold used by Frāsyāb and where today (imrōz) Š̉ād Rām Pērōz ${ }^{71}$ has built a myriad towns (Bd 9.3, 23).

Bd 10, "On the seas," describes at length the mythical ocean Frāxv kard, quoting an Avestan verse as its authority (Bd 10.6), and enumerates three salt seas

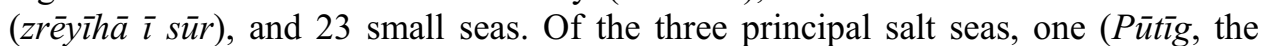
Persian Gulf) is described at length in a mythical vein. Clear identifications are provided for the two others (Bd 10.14-15): zrēh ī Kamrōd hān ì pad Abāxtar, pad Tabarestān widèrēd; hān ì Syāh-bun pad Hrōm, "the Sea of Kamrōd, which is in the North (the Caspian), is that which passes to Tabarestān; the Sea of Syāh-bun (the Black Sea) is in Byzantium." Here the compiler failed to make any mention of the Mediterranean, of which he naturally knew well; there is, of course, the possibility that he regarded the Black Sea and the Mediterranean as one and the same. ${ }^{72}$ The same chapter makes an explicit mention by name of only one of the 23 smaller salt seas, namely the 20th, Kyānseh ciyōn pad Sagestān (Bd 10.16), though large salt lakes are abundant in Iran.

Bd 11, "On the rivers,"73 describes the mythical, so to speak, "flumenology", providing 4 Avestan quotations (Bd 11.1, 3, 6, 7), and presenting in the end (Bd

\footnotetext{
$11 \mathrm{C}$ (21), "The dissatisfaction of the Arang, Marw and Hilmand rivers;" 12 (22), "On the nature of the lakes;" 29 (29), "On the chieftainship of the continents;" 31, "On particular lands of Ërānšahr, the abode of the Kays;" 32, "On the abodes which the Kays made with splendor, which are called wonders and marvels." The translation of the captions is adopted from MacKenzie (1989a).

${ }^{68}$ See Shapira (forthcoming/3), "Zoroastrian Sources on Black People".

${ }^{69}$ Kramers (1938, pp. 63a, 64a). Compare above (notes 62, 65), on the "Ardašīr”"s map, on which Iran is also at the centre.

${ }^{70}$ Based on Yt 19, of which no Zand is extant, cf. MacKenzie (1989a, p. 549a).

${ }^{71}$ Is this Pērōz son of Yazdigird III, who took refuge with the Chinese?; see also Bd 33, cf. Shapira (1998, Vol. I, Chapter 4, pp. 161, 183-186).

${ }_{72}$ However, the normal Pahlavi name for the Black Sea was not Syāh-bun, cf. Frejman (1930). So, was this Syāh-bun the Mediterranean? In should be remembered that Greeks, Arabs and Turks called the Mediterranean by the name "White Sea".

${ }^{73}$ Cf. Markwart (1938, pp. 116-117): Bd 11.1-7.
} 
11.8) the list of the 25 (though they are said to be 18) rivers between the Arang and the Weh rivers. ${ }^{74}$

Bd 11A (20) goes in further details of the list, introducing material which cannot be Avestan. Thus, Arang is said to pass through *Sūriā būm ke Š $\breve{s} m-i z^{75} x^{v} \bar{a} n \bar{e} n d$ ud pad Egiptos būm ke Misr-iz $x^{v} \bar{a} n \bar{e} n d$ be widerēd $u-s_{s} \bar{a} n \bar{o} h$ rōd $\bar{l}$ tag ${ }^{76}$ Spitoiš $x^{v} \bar{a}-$ $n \bar{e} n d$, "the land *Süriā (Syria) which is also called Šām and it passes in the land Egypt which is also called *Mișr, and there they call it the swift $(<* N \bar{\imath} l)$ river Spitoiš (<*Egyptus)" (Bd 1A.1); ${ }^{77}$ the Euphrates and Tigris on the border of Byzantium [... in Āsūrestān (Mesopotamia) [wimand $\bar{\imath}$ Hrōm pad Āsūrestān] are mentioned (Bd 1A.3-6), with a pseudo-Avestan quotation praising the Euphrates, ${ }^{78}$ with the Caspian (Kă spig; not Egypt! ${ }^{79}$ ) mentioned in Bd 11A.26. ${ }^{80}$

The order of the rivers given in $\mathrm{Bd} 11.8$ and $\mathrm{Bd} 11 \mathrm{~A}$ are different, with the latter list containing a river not mentioned in the former.

Bd $11 \mathrm{C}(21)$, "The dissatisfaction of the Arang, Marw and Hilmand rivers," is of mythical character and adds nothing to our study.

Bd 12 (22), "On the nature of the lakes," where 9 lakes are enumerated; it is

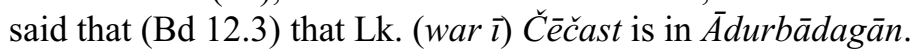

Bd 29 (29), "On the chieftainship of the continents," has mythical material interspersed with some later interpolations, such as Dašt $\overline{1}$ Tāzīgān, Sagistān, Kābulestān, Turkestān, Čēnestān, the identifications of Ėrān-Wēž with Ādurbādagān, and with Yima's vara said to be located in the middle of Pārs. ${ }^{81}$

${ }^{74}$ Arang rōd, Weh rod, Diglat rod ku Dajtar-iz x ānēnd, Frāt rōd, Dāitī rōd, Dargām rōd, Zan rōd, Harēw rōd, Marw rōd, Hētōmand rōd, Axošēer rōd, Wataēnē rōd, Zišsmund rōd, X rōd, $X^{v}$ ajand rōd, Baxl rōd, Mihrān rōd ku Hindūgān rōd-iz x $x^{v} \bar{a} n \bar{e}$ d, Spēd rōd, Tord rōd ke Kōr-iz x $x^{v} \overline{-}-$ nēnd, Xvarēy rōd ke Masragān-iz $x^{v} \bar{a} n \bar{e} n d$, Araz rōd, Turmēd rōd, Wandasī̌s rōd, Dārājā rōd, Kāsag rōd, Šèd rōd, Paydāgmehān [rōd] i Čihrōmēhan āb Mukrestān rōd.

${ }^{75}$ Or: $k \bar{e}-\bar{s} \bar{A} m i-z x^{v} \bar{a} n \bar{e} n d, " w h i c h$ they call Ami", *Amu[-Daryā].

$76 *$ Nill $(ر)>$ nyw $\left(l_{\perp \perp)}>T B(ع)>t k(ع)\right.$ )?

${ }^{77}$ This passage can be dated by the period before Husrau II; cf. interesting remarks in Shahbazi (1990, p. 214).

${ }_{78}$ Four quotations at all are found in this chapter.

${ }^{79}$ Cf. Markwart (1938, p. 5); Monchi-Zadeh (1975, p. 198ff.); Čunakova (1997, p. 295, note 315); compare Ajklesaria (1956, pp. 111-112).

${ }^{80}$ Using this opportunity, I'd like to suggest, with reservation, two possible identifications of hydronyms appearing in Bd 11A.19-20 that elluded me earlier (see Shapira 1999-2000,

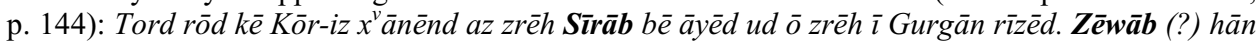
rōd $\bar{l}$ az Ādurbādagān bē āyēd ud pad Pārs ō zrēh rīzéd (cf. note 74 above), "the river Tord which they also call Kōr (Kura, Mtkvari), comes from Sīrāb and pours into the Lake of Gurgān (the Caspian). Zēwāb (?) is that river which comes from Ādurbādagān and pours in Pārs into the sea." The name of the Lake of Sīrāb does not, apparently, mean "well-watered place"; sēr here might mean "tired, disgusted; garlic", and could rather refer to the salt lake of Van; another possibility is to compare the hydronym to the Turkish name of the lake Çıldır, located near the source of Kura, whose name is connected in Turkish with the notions "to become crazy, disgusted"; or should one emend to *Sū $r-\bar{a} b$, "salt water?" As to the problematic Z Zēwāb, could this be emended to *Zab?

${ }^{81}$ Of interest is a possible (though problematic) reference to Turks, found in Bd 29.8: Sām rāy gōwēnd ku: ahōš būd, pad hān ka-š tarr-mēnīd Dēn ì Mazdaēsnān, Turk è kē Nāyōn x $x^{v} \bar{a} n e \bar{n} d$ ka xvaft êstād, pad têr bē winast, "Of Sām they say that he was immortal, at the time when he scorned the Mazda-worshipping Religion, a Turk called Nāyōn slew him with an arrow, when he was 
Bd 32, "On the abodes which the Kays made with splendour, which are called wonders and marvels," contains only mythical traditions; among these, only one new notion is worth noting, that one of the abodes of Dahāg was in Babylon, ${ }^{82}$ another in Sambarān, i.e., in Himyar, and another one in Hindūstān, i.e., in non-Iranian lands, while that of Jam / Yima was in Pārs, i.e., in Iran par excellence (Bd 32.4, 7, 8).

To sum up, these "geographical" chapters are, with the exception of Bd 8 (11), merely lists, like Bd 31, and it is plausible to suggest that the format of the list of the Avestan lands derived from the Zand of Vd 1 served as the pattern for other lists as well.

\section{VI}

Bd 14 does not belong to the "geographical" chapter in the proper sense of the word, but it contains a tradition bearing on our discussion of Sasanian geographical percepts (Bd 14.36-39): it is said there that nine of the 15 "sorts", sardag, born of Syāmag and his spouse Wašag, crossed the ocean Frāx ${ }^{\mathrm{v}}$ kard from the central kišwar $\mathrm{X}^{\mathrm{V}}$ anirah, wherein we live, to the other six mythical kišwars, borne on the back of the Bull Srisōg; six other sardags remained in the kišwar $\mathrm{X}^{\mathrm{V}}$ anirah; from these sprung the Arabs, Iranians, Māzandarānīs; it is stated that those in Iran and non-Iran, Byzantium (Salm dah hast $\bar{\imath}$ Hrōm), Tūr, China (Sēn dah hast $\bar{\imath}$ Čènestān), Dāy-dah, Sind, and even those who are in the other six kišwars - all are the descendants of Frawāg son of Syāmag son of Mašyā. All these 15 sardags, the descendants of Frawāg living in the seven kišwars, and another ten sardags, which are fabulous creatures (such as "those with eyes in their breasts, those who have wings like bats, war-̌̌ašm, èwagpay, hān-iz kē dar dārēd ciyōn šabāg, etc."), but also monkeys, are said to descend from Gayōmard.

Only later, two new "sorts" sprang, due to the intermixture caused by the Adversary, namely the "Negroes" and another "sort", designated by the word that some scholars read as "Slavs". 83

sleeping [...]." Nāyōn means "prince" in Mongolian, and this word was borrowed by Turkic and

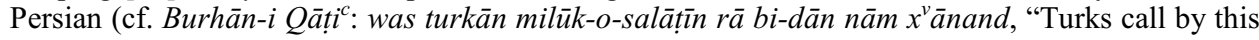
name their kings and rulers"). Another possibility is to emend Nāyōn and to read the Turkic word *tōy̌n, "a Buddhist priest", cf. Clauson (1972, p. 568a): "a high official;" cf. Doerfer (1963-1975). In both cases, the Bd passage therefore should be of a post-Sasanian date.

${ }^{82}$ Ajklesaria (1956, pp. 268-269), read its name as Korênd Dûsît / Kvirinta Duzita [TD2 = Anklesaria (1908, p. 209 1. 8): sسراصس sf. TD2, Anklesaria (1908, p. 2111.3 (Bd 32.15), where the same word is used $(\mathcal{l}, s)$, was translated in Ajklesaria (1956) as "was just-like $a$ crane (kôrêng)"'].

${ }^{83}$ The text [Bd 14.39 (TD2, Anklesaria (1908, p. 107 1. 11-13] is as follows: did pad

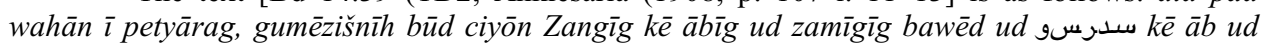
zamīg har dō zīwēd, "again, because of the Adversary, the Mixture occurred, such as Zangīg (Black Africans), who are (those) of water and (those) earth, and سدرسو, who live in both water and earth." The word in question could be read as giläbig ("of clay and water"), so Ajklesaria (1956, pp. 134-135), or as Sagläbig, so Monchi-Zadeh (1975, pp. 98-99 and note 9). The problem is that though Sasanian Iranians were aware of the Black Africans, it remains highly uncertain whether they could have any knowledge of Slavs, so if the passage under consideration dates to the Sa- 


\section{VII}

As we have seen, the Bd material provides no stuff which could be seen as something similar to geographical science, even in the loosest sense: all we have is mythology, i.e., the geographia sacra of the "Old Country", with some more recent additions (whose aim was to sanctify the Ērān Wēž / $X^{\mathrm{v}}$ anirah of the day, i.e., Sasanian Iran), and lists of provinces or towns. There is, too, "The Wonders of Sīstān", ${ }^{4}$ a valuable example of a short collection of local traditions, whose genre is perhaps somehow connected to the Arabic and Persian $m a d h$ or ${ }^{c} a j \bar{a}^{j} i b$ literature of the later date.

However, it is wrong, in my opinion, to state that the Late Sasanian Iranians knew no geography. In fact, we have a striking example of it in the Pahlavi Ayādgār $\bar{\imath}$ Jāmāspīg $[=\mathrm{AyJ}] .{ }^{85}$ In form, this is a revelation similar in many respects to that found in Zand $\overline{1}$ Wahman Yasn [ZWY]. ${ }^{86}$ It is impossible now to dwell upon the differences of structure and genre, though they are of importance.

I will say only that among the abundant eschatological material found in AyJ, some purely geographical chapters are found, and I think their inclusion into the framework of this particular composition was meant to provide a "scriptural" legitimisation for the geographical science as such.

AyJ 4.41-45 retells the story of the division of $\mathrm{X}^{\mathrm{V}}$ anirah among Frēdōn's three sons, with Ērič getting Iran and India, Tōz getting Turkestān, and Salm getting Byzantium. This story has numerous parallels, of course, but here we will note only that in our case the date is clearly Sasanian, for in the post-Sasanian versions Arabs are associated either with Salm (because of the words musulmān, Islām) or with Tōz (because of the word $t \bar{a} z \bar{\imath} g \bar{a} n)$, but here are no Arabs yet. ${ }^{87}$

AyJ 5 provides some information about the people who dwell in the six other kišwars. They are said to confess the religion of the forefathers, i.e., the religion of Gayōmard and Syāmag, and to sacrifice to Srōš.

\footnotetext{
sanian Period, the reading "Slavs" is impossible. But, if this passage dates from the post-Sasanian period, which is plausible, Slavs could be mentioned and the description of their ways of life in places abundant in water, provided by the Zoroastrian compiler, fits well the contemporary descriptions of the Eastern-European tribes, among them Slavs, Rus' and others, which are found in Arabic geographical works of the 9th-10th centuries. Another relevant passage is found in the Pahlavi Ayādgār $\bar{\imath} J \bar{a} m \bar{a} s p \bar{\imath} g$ [AyJ] 10 [see Messina (1939, pp. 53-54, translation: p. 104); cf. Appendix], where the word looking like sagläbìg was taken by the editor as referring to Cylon (Sïlän); but cf. Monchi-Zadeh (1975, pp. 98-99 and notes 8-9). However, Bd 14B depicts the "Negroes" as descendants of humans and demons and even mentions them in Southern Iran; here I trace a reference to the Zinj revolt of $868-883$ in the marshes of Southern Irāq under the guidance of alBarqu $\bar{u}^{\mathrm{C}} \overline{1}$, "the veiled", and as such, the passage is clearly of a post-Sasanian date; the same may be deduced also regarding our "Slavic" passage. On a Persian etymology of saglāb found in Gardīzī, cf. Martinez (1983, p. 125). As to these "Negroes", see Shapira (forthcoming/3): Zoroastrian Sources on Black People.

${ }^{84}$ Cf. West (1916); Utas (1983); cf. also Utas (1976).

${ }^{85}$ See Messina (1939).

${ }^{86}$ For Zand $\bar{\imath}$ Wahman Yasn, see Cereti (1995).

${ }^{87}$ As in Abdīh ì Sìstān 4.
} 
People of the strange "sorts" already mentioned in the context of Bundahišn are described at some length in AyJ 9. This tradition ultimately goes back to Classical geography, and must be an import from Greek or Syriac sources.

If in AyJ 10 the Pahlavi text spoke of Cylon, as Messina believed, then the source should also be Classical (compare Anania of Širak, where the arrangement of material is similar).

AyJ 12.2-7 depicts the land of Māzandarān; in the Late Sasanian period this country was still non-Iranian and hardly Zoroastrian at all; ${ }^{88}$ the description seems to derive from a lost Nask quoted in Dēnkard IX.10, for which our AyJ provides valuable textual variants. ${ }^{89}$

But the most interesting and real-geographical information is found in AyJ 8, which deals with the Turks, ${ }^{90}$ Chinese, Arabs, Berbers, and in AyJ 12.8-16, which treats of the Turks [see Appendix]. Though short, these texts on the Turks and the Chinese read like the descriptions of Muslim geographers (e.g., Gardī $\bar{z} \mathbf{1}^{-1}$ or Marwazi ${ }^{-92}$ ) of the same peoples.

We should remember that our knowledge of many aspects of the Sasanian civilisation is, and will remain, limited. Nevertheless, it seems to me safe to state that the Sasanian Iranians did not develop a geographical science which can be compared to that of the Greek- and Arabic-writing authors. It seems that even the actual geographical knowledge of their own country that the Sasanian Iranians possessed was barely systematised, and was rather treated in accordance with geopolitical and/or religious attitudes, characterised by Iranocentrism.

\section{Appendix}

AyJ 8.1. pursìd Wištāsp šāh ku awēšān mardomān ì pad Hindūgān ud Cēnestān ud Turkestān ud Täzīgān ud Barbarestān jud jud dād ud rawišn cēe, u-šān zīwandagīh ud nēwagìh ciyōn, ka mērēend ō kü abganēnd u-šān ruwān ō kī šawēnd, "The king Wištāsp asked: 'those people who are in India, China, Turkestān, Arabia and Berberia, what are their respective religions and behavior, and their ways of life and qualities? Where are they thrown when they die, and where do their souls go?'”

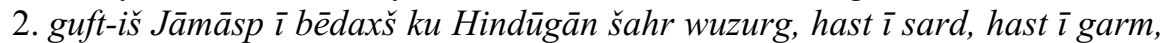
hast $\bar{l}$ tarr, hast $\bar{\imath}$ hušk, hast kī dār ud draxt, hast kū dašt $\bar{l}$ saxt hast kū wyāb, "Jāmāsp the vice-roy said to him: 'India is a vast state. In some places it is cold, in some places it is hot, in some places it is wet, in some places it is dry, there are trees and shrubs, there are heavy deserts where one goes astray."

\footnotetext{
${ }^{88}$ Cf. Brunner (1983, p. 766).

${ }^{89}$ See Shapira (forthcoming/2): Between Himyar and Māzandarān: Pahlavi Traditions of Husraw Anōšurwān's Wars.

${ }^{90}$ In fact, Turks are dealt with in AyJ 12, cf. below.

${ }^{91}$ Cf. Martinez (1983).

${ }^{92}$ See Minorsky (1942). 
3. hast kēešann zīwišnīh az brinj, hast kēe az šìr $\bar{l}$ gāw, hast ke <az> tohmīhā $x^{v} \bar{a} r \bar{e} n d$, "There are some whose living is on rice, there are some whose living is on cow-milk, there are some who eat $<$ from $>$ fruits (or, eggs)."

4. u-šān kēš ud dād ud rawišn was, ud hast $\bar{l}$ pad nēmag $\bar{\imath}$ Ōhrmazd, ud hast $\bar{\imath}$ pad nèmag $\bar{\imath}$ Ahriman ud jādūgīh āškārag kunēnd, "Their faiths and religions and ways of life are multiple. There are some who are in the (half-)lot of Ōhrmazd, there are some who are in the (half-)lot of Ahriman, and they practice witchcraft publicly."

5. ud ka mīrēnd, hast kē andar zamīg nigān kunēnd, ud hast kē ō àb abganēnd, ud hast kē pad āta[x]š bēe sōzēnd, ud harw kē nē hudēn ō Dušax v̌ šawènd, "When they die, there are some who bury (their dead) in the earth, and there are some who throw (their dead) into water, and there are some who burn (their dead) with fire, and everyone who is not of the Good Religion goes to Hell."

6. ud Cēnestān šahr wuzurg ī was-zarr ud was-mušk ud was-gōhr, mardomān ìs andar bawēnd kirrōg ud nēzūmān ud bārīg wēnišn èstād bawēnd, But paristēnd, ka mèrēnd, druwand hēnd, "The state of China is vast, having much gold, much muscus, much jewels, and the people who live in it are artisan and dextrous and of thin complexion, they worship Buddha, they are unrighteous in their death."94

${ }^{93}$ Our text speaks, however, of an ambivalent attitude toward the inhabitants of India, some of whose religious practices were indeed sometimes resembling those of Zoroastrians, due to the common ancestry and the later Iranian impact. But sometimes these were just the opposite of the Zoroastrian cult. It would be interesting to trace the history of Zoroastrian attitudes to Indian religions up to our days [cf. Hinnells (1994)]. It is not necessary to presume that huden in India meant specifically "Zoroastrian"; the term may refer to the Hinduized Magi of Mithra who settled in India, cf. Humbach (1978). As to the supposed statements about Zoroastrians in India and in Turkestān, it should be remembered that the Iranian, Median pre-Zoroastrian cult of Mithra xša known in Egypt [on a Mythraion used by Persian soldiers at the end of the Achæmenian rule, if not later, see Boyce (1982, pp. 186 \& 265)] and the Near East, including Phoenician cities of the mainland, Cyprus and Carthago, and it is quite possible that Alexander used this cult in his propaganda against the Achæmenids, the stubborn Mazdæans [see Bivar (1994, p. 69); cf. Bivar (1975)].

The Indians and Chinese were both held in great esteem by the Iranians of the Late Sasanian period. Indian wisdom was transferred into Iran as part of the project of assembling the dispersed Avesta, and many "secular" works were translated as well, so, Kalīlah wa-Dimnah, TütīiNāmah, Sindbād-Nāmah were translated circa 550, i.e., about the time when the Avesta was codified. On Indian motifs penetrating Greece and Syria via Sasanian Iran, cf. Shaked (1984, pp. 49-50); see now de Blois (1990).

${ }^{94}$ This is a fitting description of pre-T'ang China (except, of course, the idea that the Chinese go to Hell, and therefore have no hope of salvation), since Li Shi-min (the Emperor Tai Tsung, the founder of the T'ang Dynasty, 618-907) opposed Buddhism and promoted the teachings of Confucius, and in 624 the great debate against Buddhism was held at the royal court, recorded by Fu I (555-639). Buddhism became popular in China only after the fall of the Han Dynasty in the 3rd century $\mathrm{AD}$, although the penetration of this religion began as early as the 1st century from Tibet. Later, the Parthian and Kushan Iranians played an important role in bringing the Buddhist gospel to China, a Parthian prince Aršak (An Shih-kao, An Shi-gao), a Sogdian K'ang Seng-hui and a Parthian merchant An Hsüan (Xuan) among them. In the 4th century Buddhism became the state religion of China. At the end of the same century, Chinese Buddhism penetrated Korea, and about 552, this religion appears in Japan, via Korea. When the Zoroastrians first appeared in China in the early 6th century, their religion was spared from the general persecution of foreign religions (Watson 1983, p. 554). However, in the Huichang (841-846) epoch many sects were suppressed in China. All this perhaps indicates a pre-T'ang date. 
7. Tāzīgān ud Barbarestān šahr garm ud hušk wyābān, nēst bar ud āb tang $u$ šān $x^{v}$ arišn šìr ud xrafstarān ud mūš ud mār ud gurbag, rōbāh ud kaftār ud abārīg az $\bar{e} n$ èwēn, uzdēs paristēnd $u$-š̄̄n ż̄wišn az uštr ud cahār-pād, any ciš nēst, "The land[s] of Arabs and Berbers is a hot and dry desert, it has no fruits and water is scarce, and their food is milk and xrafstras (noxious creatures) and mice and snakes and cats, foxes and hyenas and others of that kind, they worship images/statues and their living is on but camels and quadrupeds, having nothing else.",95

AyJ 12.8-9: Turkestān wuzurg gyāg ud hamāg sard, wēšag bawēe, u-šān draxt $\bar{\imath}$ barwar ud mēwag $\bar{\imath} x^{v}$ arišnīg ud *any ciš nihang. Hast az awēšān kēe Māh paristēnd ud hast kē jādūg hēnd, ud hast $\bar{\imath}$ Weh-Dēn hēnd, "Turkestān is a vast place and all of it is cold, it is forests, they have few fruit-trees and edible fruits and [other edible] things. There are some among them who worship the Moon and there are some who are sorcerers, and there are some who are of the Good Religion."96

AyJ 12. 15: Warz ̄̄ ābādānīh kunēnd. ka mērēnd $\bar{o}$ wēšag abganēnd, ud hast $\bar{l} \bar{o}$ Wahišt ud hast $\bar{l} \bar{o}$ Dušax ${ }^{v}$ ud Hamēstagān šawēnd, "They till the land. When they die, they throw (their dead) in forests, and there are some who go to Paradise, and there are some who go to Hell and the mixed place."

\section{References}

Ajklesaria, B. T. (1956): Zand-Ākāsīh, Iranian or Greater Bundahišn. Transliteration and Translation in English. Bombay.

Anklesaria, T. D. (1908): The Bûndahishn. Being a Facsimile of the TD Manuscript No. 2 Brought from Persia by Dastur Tîrandâz and Now Preserved in the Late Ervad Tahmuras' Library. Bombay.

Back, M. (1978): Die sassanidischen Staatsinschriften. Studien zur Orthographie und Phonologie des Mittelpersischen der Inschriften zusammen mit einem etymologischen Wortgutes und einem Textcorpus der behandelten Inschriften. Leiden-Téhéran-Liège (Acta Iranica, Vol. 18, Troisième série, Textes et mémoires Vol. VIII).

Bivar, A. D. H. (1975): Mithra and Mesopotamia. In: J. R. Hinnells (ed.): Mithraic Studies. Manchester, pp. 275-289.

Bivar, A. D. H. (1985): The Persian Fairyland. Acta Iranica, Vol. 24 (deuxième série, Hommages et Opera Minora XI. Papers in Honour of Professor Mary Boyce, Vol. I). Leiden, pp. 25-42.

\footnotetext{
${ }^{95}$ In my opinion, it is fairly clear that this description of Arabia is of pre-Islamic origin; the importance of uzdess (which might indicate both pagan and Christian objects of worship) for this dating is uncertain, but the tone is not hostile. We are told nothing about *dād $\bar{l}$ wad $\bar{\imath}$ Tãziggann, * "the evil Arab religion", which means Islam, and Berberia could have been mentioned only during the short period of the Sasanian occupation of the Western outskirts of Siwah and Fayoum. However, Messina (1939, p. 162, note 1), was of the opinion that by Barbarestān here Eastern Africa (Somaliland) is meant; in the last case, the date could be the last years of the reign of Husrau I and later (577-). For Barbarestān in the East of Iran, compare Monchi-Zadeh (1975, pp. 88-91); cf. Bivar (1985, pp. 25-42).

${ }^{96}$ According to Boyce (1987, p. 127), it is interesting to note that "there were Zoroastrians among the Hindus, AyJ 8.4-5, and Turks, AyJ 12.9". However, compare Shapira (forthcoming/1).
} 
Bivar, A. D. (1994): Towards an Integrated Picture of Ancient Mithraism. In: Hinnells, J. R. (ed.): Studies in Mithraism. Rome, pp. 61-74.

de Blois, F. (1989): Maka and Mazūn. Studia Iranica, Vol. 18, pp. 157-167.

de Blois, F. (1990): Burzōy's Voyage to India and the Origin of the Book of Kalīlah wa Dimnah. London, Royal Asiatic Society (Prize Publication Fund Vol. XXIII).

Boyce, M. (1968): The Letter of Tansar. Literary and Historical Texts from Iran. Roma (Serie Orientale Roma XXVIII, Persian Heritage Series).

Boyce, M. (1982): A History of Zoroastrianism, Vol. II. Leiden (Handbuch der Orientalistik).

Boyce, M. (1987): Ayātkār ̄̄ Jāmāspīg. In: Encyclopcedia Iranica, Vol. II. London-New York, pp. 127-128.

Brunner, Ch. (1983): Geographical and Administrative Divisions: Settlements and Economy. In: Ehsan Yarshater (ed.): The Cambridge History of Iran 3(2), The Seleucid, Parthian and Sasanian Periods. Cambridge-London-etc., Cambridge University Press, pp. 747-777.

Cantera Glera, Nicolás Alberto (1998): Estudios sobre la traducción páhlavi del Avesta: las versiones avéstica y páhlavi de los cuatro primeros cap'tulos de Videvdad. Vols I-II, PhD thesis, Salamanca.

Cereti, C. (1994): Zoroastrian Pahlavi Literature as a Source for Central-Asian Geography, The Archeology of the Steppes. In: Methods and Strategies. Papers from the International Symposium Held in Naples 9-12 November 1992, Istituto Universitario Orientale. Dipartimento di Studi Asiatici. Napoli (Series Minor XLIV), pp. 447-466.

Cereti, C. (1995): The Zand $\bar{\imath}$ Wahman Yasn. A Zoroastrian Apocalypse. Roma, Istituto Italiano per il Medio ed Estremo Oriente (Serie Orientale Roma fondata da Giuseppe Tucci diretta da Gherardo Gnoli Vol. LXXV).

Cereti, C. (1995-1997): Primary Sources for the History of Inner and Outer Iran in the Sasanian Period. Archivum Eurasiae Medii Aevi, Vol. 9, pp. 17-72.

Christensen, A. (1943): Le premier chapitre du Vendidad et l'histoire primitive des tribus iraniennes. Copenhagen.

Clauson, G. (1972): An Etymological Dictionary of Pre-Thirteenth Century Turkish. Oxford.

Corbin, H. (1977): Spiritual Body and Celestial Earth. From Mazdean Iran to Shĩ ite Iran. Princeton (= Terre céleste et corps de résurrection: de l'Iran mazdéen à l'Iran shĩ ite. Paris 1960).

Čunakova, O. M. (1997): Zoroastrijskije teksty. Suždenija Duxa Razuma (Dadestan-i menog-i xrad). Sotvorenije Osnovy (Bundaxišn) i Drugije Teksty. Moscow, Vostočnaja literatura.

Dastoor Hoshang Jamasp (1907): Vendidâd. Avesta Text with Pahlavi Translation and Commentary, and Glossarial Index, edited by Shams-ul-Ulma, Sirdar, Khan Bahadur Dastoor Hoshang Jamasp, Parsi High-Priest of the Deccan, etc., with the Assistance of Mervanji Manekji Gandevia, M. A. Vol. I: The Texts. Bombay.

Doerfer, G. (1963-1975): Türkische und mongolische Elemente im Neupersischen. Vols I-IV. Wiesbaden.

Frejman, A. (1930): Nazvanije Černogo Morja v domusul'manskoj Persii. Zapiski Kollegii Vostokovedov V / Mémoires du Commité des Orientalistes (Leningrad), Vol. V, pp. 647-651.

Geiger, W. (1904): Geographie von Iran. In: Grundriss Iranischer Philologie. Vol. II.3, pp. 371-394.

Gignoux, Ph. (1971): La liste des provinces de l'Ērān dans les inscriptions de Šābuhr et de Kirdīr. Acta Antiqua Academiae Scientiarum Hungaricae, Vol. 19, pp. 83-94.

Gignoux, Ph. (1984): Les quatre régions administratives de l'Iran sasanide et la symbolique des nombres trois et quatre. Annali dell'Istituto Universitario Orientale (Napoli), Vol. 44.4, pp. $555-572$. 
Gignoux, Ph. (1985): L'organisation administrative sasanide: le cas du marzbān. Jerusalem Studies in Arabic and Islam Vol. 4 [From Jāhiliyya to Islam, Colloquium, Jerusalem, June 1980], pp. 1-29.

Gignoux, Ph. (1987): Anērān. In: Encyclopcedia Iranica. Vol. II. London-New York, pp. 30-31.

Gignoux, Ph. (1991): Les quatre inscriptions du mage Kirtīr. Textes et concordances. Paris (Collections de sources pour l'histoire de l'Asie Centrale pré-islamique Série II, Vol. I; Studia Iranica, Cahier 9).

Gignoux, Ph. (1992): À propos de la géographie administrative sassanide. Revue Numismatique $\mathrm{VI}^{\mathrm{e}}$ série, Vol. 34, pp. 242-245.

Gnoli, Gh. (1980): Zoroaster's Time and Homeland. Naples.

Gnoli, Gh. (1985): Ēr Mazdēsn. Zum Begriff Iran und seiner Entstehung im 3. Jahrhundert. In: Transition Periods in Iranian History (Actes du Symposium de Fribourg en Brisgau), pp. $83-100$

Gnoli, Gh. (1986): Mitteliranisch ēr „Iranier“. In: Schmidt, R. - Skjærvø, P. O. (eds): Studia Grammatica Iranica (Festschrift für H. Humbach). München, pp. 115-124.

Gnoli, Gh. (1989): Avestan Geography. In: Encyclopcedia Iranica. Vol. III, London-New York, pp. $44-47$.

Gnoli, Gh. (1998): Two Historical Questions Relating to the Alans and the Mountains. In: Gnoli, Gh. - Gusalov, V. M. - Rossi, A. V. (eds): Studia Iranica et Alanica: Festschrift for Prof. Vasilij Ivanovič Abaev on the Occasion of His 95th Birthday. Roma, Istituto Italiano per l'Africa e l'Oriente, Instituto Universitario Orientale, Dipartamento di Studi Asiatici and North-Ossetan Institute of Humanities, Cultural Anthropology Department, pp. 161167 (Serie Orientale Roma, Fondata da Giuseppe Tucci, Diretta da Gherardo Gnoli, Vol. LXXXII).

Golden, P. B. (1984): Khazaria and Judaism. Archivum Eurasiae Medii Aevi, Vol. 4, pp. 126-156.

Gyselen, R. (1989): La géographie administrative de l'Empire sassanide. Paris (Res Orientalies, I).

Henning, W. B. (1939): The Great Inscription of Šāpūr I. Bulletin of the School of Oriental and African Studies, University of London, Vol. 9, pp. 823-849.

Henning, W. B. (1954): Notes on the Great Inscription of Šāpūr I. In: Prof. Jackson Memorial Volume. Bombay, pp. 40-54

Hewsen, R. H. (1992): The Geography of Ananias of Šrak (Ašxarhac oyc ${ }^{c}$ ). The Long and the Short Recensions. Introduction, Translation and Commentary. Wiesbaden (Beihefte zum Tübinger Atlas des Vorderen Orients, Reihe B - Geisteswissenschaften, Nr. 77).

Hinnells, J. R. (1994): South Asian Diaspora Communities and their Religion: A Comparative Study of Parsi Experiences. South Asia Research, Vol. 14.1, pp. 62-104.

Honigmann, E. - Maricq, A. (1953): Recherches sur les Res Gestae Divi Saporis. Bruxelles, Académie Royale de Belgique ( $\mathrm{Cl}$. des Lettres et des Sciences Morales et Politiques, Mémoires 47.4).

Humbach, H. (1960): Die awestische Länderliste. Wiener Zeitschrift für die Kunde Süd- und Ostasiens, Vol. 4, pp. 34-46.

Humbach, H. (1978): MiӨra in India and the Hindoized Magi. In: Études Mithraiques. TéhéranLiège (Acta Iranica 17), pp. 229-252.

Justi, F. (1869): Beiträge zur alten Geographie Persiens. Marburg.

Kasumova, S. Ju. (1994): Srednepersidskaja épigrafika Kavkazskoj Albanii (Derbent). Goroda Irana. Baku, Elm.

Kiā, S. (1958): Suğd-e haft-āšiyān. In: Majalle-yi Dāneškade-e Adabiyāt-e Dānešgāh-e Tehrān, šomāre 5, sāl-e dovvom (Farvardīn Māh 1334), pp. 47-49.

Kiā, S. (1975): Soyd-e Haft Āšiyān. Acta Iranica, Vol. 4, pp. 471-473. 
Kolesnikov, A. I. (1970): Iran v načale VII veka (istočniki, vnutrennjaja i vnešnjaja politika, voprosy administrativnogo delenija). (Palestinskij Sbornik, 22/85).

Kolesnikov, A. I. (1981): O termine 'marzban' v Sasanidskom Irane. (Palestinskij Sbornik, 27/90)

Kolesnikov, A. I. (1982): Zavojevanie Irana arabami. Moscow, Nauka.

Kramers, J. H. (1938): Djughrāfiyā. In: Houtsma, M. Th. - Wensinck, A. J. - Gibb, H. A. E. Heffening, W. - Lévi-Provençal, E. (eds): The Encyclopaedia of Islam. A Dictionary of the Geography, Ethnography and Biography of the Muhammadan Peoples Prepared by a Number of Leading Orientalists. Supplement. Leiden-London, pp. 61-73.

MacKenzie, D. N. (1989a): Bundahišn. In: Encyclopcedia Iranica. Vol. III, London-New York, pp. $547-551$.

MacKenzie, D. N. (1989b): Kerdir's Inscription, The Sasanian Rock Reliefs at Naqsh-i Rustam. Naqsh-i Rustam 6, The Triumph of Shapur I (together with an account of the representations of Kerdir), ed. G. Herrmann, Iranische Denkmäler L.13 r. II, Iranische Felsereliefs I., Berlin.

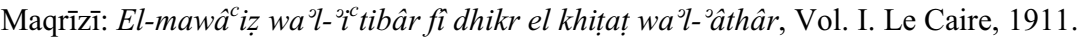

Maricq, A. (1958): Res Gestae Divi Saporis (=Classica et Orientalia 5). Syria, Vol. 35, pp. 295-360.

Markwart, J. (1938): Wehrōt und Arang. Leiden.

Markwart, J. - Messina, G. (1931): A Catalogue of the Provincial Capitals of Ērānšahr (Pahlavi Text, Version and Commentary), ed. by G. Messina S. I. Roma, Pontificio Istituto Biblico.

Marquart, J. (1901): Ërānšahr nach der Geographie des Ps. Moses Xorenac i. Mit historisch-kritischem Kommentar und historischen und topographischen Excursen. Berlin (Abhandlungen der Königlichen Gesellschaft der Wissenschaften zu Göttingen, Phil.-hist. Klasse, Neue Folge. Bd. III aus den Jahren 1899-1901).

Marquart, J. (1903): Osteuropäische und ostasiatische Streifzüge. Leipzig.

Martinez, A. P. (1983): Gardīzī’s Two Chapters on the Turks. Archivum Eurasiae Medii Aevi, Vol. II, pp. 109-218.

Mehren, M. A. F. (1866) [ed.]: Cosmographie de Dimichqui, texte arabe. Saint-Pétersbourg.

de Menasce, P.-J., O. P. (1945): Škand-Gumānì̀k Vičārr, La solution décisive des doutes. Fribourg en Suisse.

Messina, G. (1939): Libro apocalittico persiano Ayātkār ì Žāmāspīk. Roma (Biblica et Orientalia 9).

de Meynard, B. - de Courteille, P. (1914): Maçoudi, Les Prairies d'Or, Murūj al-Dhahab. Texte et traduction par C. Barbier de Meynard et Pavet de Courteille, Société Asiatique, 9 vols. Paris (first published Paris 1861-1877; revised and corrected by C. Pellat, Paris 1962).

Minorsky, V. (1942): Sharaf al-Zamān Tāhir Marvazì on China, the Turks and India. Arabic Text (circa A.D. 1120) with an English Translation and Commentary. London, The Royal Asiatic Society (James G. Forlong Fund Vol. XXII).

Molé, M. (1951): La structure du premier chapitre du Videvdat. Journal Asiatique, Vol. 229, pp. 283-298.

Molé, M. (1967): La Legende de Zoroastre selon les Textes Pehlevis. Paris (Travaux de l'Institut d'Études Iraniennes de l'Université de Paris 3, ed. J. de Menasce).

Monchi-Zadeh, D. (1975): Topographisch-historische Studien zum Iranischen Nationalepos. Wiesbaden (Abhandlungen für die Kunde des Morgenlandes, Bd. XLI, 2).

Morony, M. G. (1982): Continuity and Change in the Administrative Geography of Late Sasanian and Early Islamic al- ${ }^{\mathrm{c}}$ Irāq. Iran, Vol. XX, pp. 1-50.

Nyberg, H. S. (1938): Die Religionen des alten Iran. Leipzig.

Shahbazi, A. Sh. (1990): On the $X^{w}$ adāy-Nādmag. Acta Iranica, Vol. 30, pp. 208-229.

Shaked, Sh. (1984): From Iran to Islam: Notes on Some Themes in Transmission. Jerusalem Studies in Arabic and Islam, Vol. 4, pp. 31-67. 
Shaked, Sh. (1985): Bagdāna, King of Demons, and Other Iranian Terms in Babylonian Aramaic Magic. Acta Iranica, Vol. 24 (deuxième série, Hommages et Opera Minora XI. Papers in Honour of Professor Mary Boyce, Vol. I, Leiden), pp. 511-542.

Shaki, M. (1985): The Cosmogonial and Cosmological Teachings of Mazdak. Acta Iranica, Vol. 25 (deuxième série, Hommages et Opera Minora XI. Papers in Honour of Professor Mary Boyce, Vol. II, Leiden), pp. 527-544.

Shapira, D. (1998): Studies in Zoroastrian Exegesis: Zand. Vols I-II, PhD thesis. Jerusalem, Hebrew University of Jerusalem.

Shapira, D. (1999-2000): Pahlavi References to Armenia, Iran \& Caucasus. In: Garnik Asatrian (ed.): Research Papers from the Caucasian Centre for Iranian Studies, Yerevan. Vols IIIIV, Teheran, pp. 143-146.

Shapira, D. (forthcoming/1): Iranian Sources on the Khazars. In: Proceedings of the First International Khazar Colloquium. Jerusalem.

Shapira, D. (forthcoming/2): Between Hịmyar and Māzandarān: Pahlavi Traditions of Husraw Anōšurwān's Wars

Shapira, D. (forthcoming/3): Zoroastrian Sources on Black People.

Skjærvø, P. O. (1983): The Sassanian Inscription of Paikuli, Part 3.1, Restored Text and Translation; Part 3.2, Commentary. Wiesbaden.

Smirnova, A. P. (1993) [ed.]: ' Ajā̄ib ad-Dunyā (Čudesa mira), kritičeskij tekst, perevod s persidskogo, vvedenie, kommentarij i ukazateli A. P. Smirnovoj. Moscow: Nauka (Pamjatniki pis'mennosti Vostoka LXXXIII).

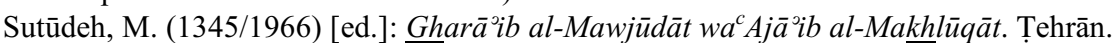

Tafazzoli, A. (1990): Pahlavica III. Acta Orientalia, Vol. 51, pp. 47-60.

Tomaschek, W. (1883): Zur historischen Topographie von Persien. Sitzungsberichte der Wiener Akademie der Wissenschaften, Phil.-hist. Kl. 102, pp. 146-231.

Utas, B. (1976): Non-Religious Book Pahlavi Literature as a Source to the History of Central Asia. Acta Antiqua Academiae Scientiarum Hungaricae, Vol. 24, pp. 115-124.

Utas, B. (1983): The Pahlavi Treatise Avdēh u sahīkēh ì Sakistān. Acta Antiqua Academiae Scientiarum Hungaricae, Vol. 28, pp. 259-267.

Watson, W. (1983): Iran and China. In: Ehsan Yarshater (ed.): The Cambridge History of Iran 3(1), The Seleucid, Parthian and Sasanian Periods. Cambridge-London-etc., Cambridge University Press, pp. 537-558.

Wehr, H. (1976): Arabic-English Dictionary: The Hans Wehr Dictionary of Modern Written Arabic, edited by J. M. Cowan. Wiesbaden, Otto Harrassowitz.

West, E. W. (1916): A Translation and Transliteration of the Pahlavi Treatise 'Wonders of Sagastān' (Sīstān), ed. by A. V. Williams Jackson. Journal of American Oriental Society, Vol. 36, pp. 115-121.

von Wüstenfeld, F. (1866) [ed.]: Múcjam al-Buldān, Vol. I. Leipzig.

Zand, M. (1988): Hityašvut ha-Yehudim b-Asyah ha-Tikhonah b-imey qedem ubh-imey haBeynayim ha-Muqdamim [Jewish Settlement in Central Asia in Ancient Times and in the Early Middle Ages]. Pe amim, Vol. 35, pp. 4-23 [Hebrew].

Zotenberg, H. (1900): Histoire des rois des Perses par Aboù Manșoûr ${ }^{c}$ Abd al-Malik ibn Mohammad ibn Ismâcil al-Thac âlibî, texte arabe publié et traduit. Paris. 